\title{
Dietary protein and changes in markers of cardiometabolic health across 20 years of follow-up in middle-aged Americans
}

\author{
Adela Hruby ${ }^{1,2}$ and Paul F Jacques ${ }^{1,2, *}$ \\ 'Nutritional Epidemiology Unit, Jean Mayer USDA Human Nutrition Research Center on Aging at Tufts University, \\ 711 Washington Street, 9th Floor, Boston, MA 02111 , USA: ${ }^{2}$ Friedman School of Nutrition Science and Policy, Tufts \\ University, Boston, MA, USA
}

Submitted 19 0ctober 2017: Final revision received 8 May 2018: Accepted 20 June 2018: First published online 17 August 2018

\begin{abstract}
Objective: Dietary protein plays a role in counteracting age-related muscle loss. However, limited long-term data exist on protein intake and markers of cardiometabolic health, which tend to deteriorate with age.

Design: Prospective cohort study. FFQ-derived protein intake (g/d) and cardiometabolic markers were assessed up to five times across 20 years. Markers included systolic (SBP) and diastolic (DBP) blood pressures, circulating lipids (total, HDL and LDL cholesterol; TAG), estimated glomerular filtration rate (eGFR), fasting glucose (FG), weight and waist circumference (WC). Mixed models accounting for repeated measures were used to estimate adjusted mean annualized changes in outcomes per quartile category of protein.

Setting: Framingham Heart Study Offspring cohort, USA.

Subjects: Participants ( $n$ 3066) with 12333 unique observations, baseline (mean $(\mathrm{SD}))$ age $=54.0(9.7)$ years, $\mathrm{BMI}=27.4(4.9) \mathrm{kg} / \mathrm{m}^{2}, 53.5 \%$ female.

Results: In fully adjusted models, there were favourable associations (mean (SE)) of total protein with annualized changes in SBP (lowest $v$. highest intake: $0 \cdot 34(0.06)$ $v .0 .04(0.06) \mathrm{mmHg}, P$ trend $=0.001)$ and eGFR $(-1.03(0.06) v .-0.87(0.05) \mathrm{ml} /$ min per $1.73 \mathrm{~m}^{2}, P$ trend $\left.=0.046\right)$, unfavourable associations with changes in FG $(0.013(0.004) v \cdot 0.028(0.004) \mathrm{mmol} / \mathrm{l}, P$ trend $=0.004)$ and no associations with weight, WC, DBP or lipids. Animal protein was favourably associated with SBP and unfavourably with FG and WC; plant protein was favourably associated with FG and WC.

Conclusions: The present study provides evidence that protein intake may influence changes in cardiometabolic health independent of change in weight in healthy adults and that protein's role in cardiometabolic health may depend on the protein source.
\end{abstract}

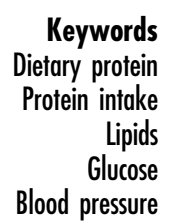

Typically making up $12-19 \%$ of energy in the average American $\operatorname{diet}^{(1)}$, protein receives relatively little attention compared with dietary fats and carbohydrates when it comes to cardiometabolic health. Evidence from shortterm randomized trials suggests that higher-protein diets (20-35\% of energy) may lower cardiometabolic risk, most notably via changes in body composition and/or weight i.e. contributing to loss of fat mass and/or mitigating loss of lean body mass ${ }^{(2-4)}$ - with inconsistent effects on other cardiometabolic risk factors $^{(2,3,5-9)}$.

Many cross-sectional studies have investigated concurrent relationships between reported intake and cardiometabolic measures, with favourable associations observed for body composition ${ }^{(1,10-12)}$, and beneficial or equivocal results for other cardiometabolic risk factors ${ }^{(1,11-13)}$. In addition, higher protein intake is thought to be more beneficial in older individuals, potentially delaying agerelated muscle loss and other cardiometabolic abnormalities $^{(7,14-17)}$. However, there is still conflicting evidence regarding the longer-term effects of high protein intake on other cardiometabolic health parameters related to ageing. Some prospective cohort studies have indicated that higher habitual protein intake increases risk of cardiometabolic end points, such as diabetes and metabolic syndrome $^{(18-22)}$, and mortality ${ }^{(14,18,19)}$, particularly in the context of low carbohydrate intake ${ }^{(23,24)}$. Other prospective studies have found beneficial associations between protein intake and blood pressure ${ }^{(25,26)}$ and risk of mortality in older adults ${ }^{(14,27)}$. Although these studies examined protein intake in relation to incident end points, 
few have examined long-term changes in cardiometabolic risk factors.

To clarify the role of protein intake in modulating cardiometabolic risk, the present study examined habitual protein intake in participants of the Framingham Heart Study Offspring cohort and its relationships with changes in cardiometabolic risk factors across up to five time points in 20 years of follow-up. Given existing literature, we hypothesized that higher protein intake would be inversely associated with changes in anthropometric measures (weight, waist circumference (WC)) and blood pressure, and directly associated with a marker of kidney function (estimated serum creatinine (sCr)-based glomerular filtration rate (eGFR)), and that we would not observe consistent relationships with glucose, insulin or circulating lipids.

\section{Experimental methods}

\section{Study participants}

The National Heart, Lung, and Blood Institute's Framingham Heart Study Offspring cohort is a community-based, longitudinal study of CVD that began in $1971^{(28)}$. In the fifth examination cycle ('baseline') of the Offspring cohort, 3799 participants underwent a standard medical examination, consisting of laboratory and anthropometric assessments, as well as dietary intake assessment. In the present study, participants were followed from the fifth exam (1991-1995) through up to the ninth exam (20112014). Individuals were excluded from the present analysis if they had missing or invalid dietary data (baseline excluded $n 381$ ); were not fasting $\geq 8 \mathrm{~h}$ (baseline excluded $n$ 30); were missing necessary covariates (baseline excluded $n 14$ ); or had no follow-up data on any exposure or cardiometabolic marker of interest $(n$ 308). The final sample size was 3066 participants with baseline data and at least one exam with follow-up data, although sample sizes varied slightly by outcome.

The original data collection protocols were approved by the Institutional Review Board at Boston University Medical Center, and written informed consent was obtained from all participants. The present study protocol was reviewed by the Tufts University Health Sciences Institutional Review Board. Data analysis took place January through September 2017.

\section{Cardiometabolic risk factors}

Outcomes included the following cardiometabolic risk factors measured at each exam: weight, WC, fasting plasma glucose (FG), systolic (SBP) and diastolic (DBP) blood pressure, fasting plasma TAG, plasma total cholesterol (TC), HDL-cholesterol (HDL-C) and calculated LDL-cholesterol (LDL-C), and eGFR. We included as secondary outcomes fasting plasma insulin (FI) and homeostatic model assessment of insulin resistance (HOMA-IR) because insulin was assessed at two exams only (exams 5 and 7).

Weight (kg) was measured using a standard scale, with the participant wearing a light gown and no shoes. WC $(\mathrm{cm})$ was measured at the umbilicus with the participant standing, at mid-respiration. FG was measured in fresh specimens with a hexokinase reagent kit (A-Gent glucose test; Abbot, South Pasadena, CA, USA). At each exam, SBP and DBP were measured twice by a physician using a sphygmomanometer and averaged. Plasma TAG, TC and HDL-C were measured using enzymatic/colorimetric methods. LDL-C was calculated per the Friedewald equation modified by Martin et al., to account for varying nonHDL-C and TAG concentrations as: TC - HDL-C - (TAG/

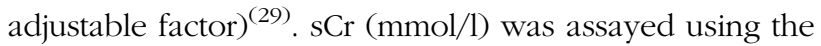
modified Jaffé colorimetric method (Roche Hitachi 911; Roche Diagnostics, Indianapolis, IN, USA) and calibrated as previously described ${ }^{(30)}$. We estimated eGFR using calibrated $\mathrm{sCr}^{(31)}$ in the CKD-EPI Equation for white participants $^{(32)}$, calculated as previously described ${ }^{(33)}$. At exam 5, plasma FI (mU/ml) was measured using the CoatA-Count total insulin RIA (Diagnostic Products Corp., Los Angeles, CA, USA), while at exam 7, FI was measured using the human-specific insulin RIA (Linco Research Inc., St. Charles, MO, USA). HOMA-IR was calculated per the equation of Matthews et al. ${ }^{(34)}$.

\section{Protein and other dietary intake}

The Harvard semi-quantitative, 126-item FFQ was used to assess dietary intake at each exam ${ }^{(35)}$. The FFQ included a list of foods for which participants were asked to report frequency of consumption of standard serving sizes of each food item over the previous year. Possible response frequencies ranged from never/ $<1$ time per month to $\geq 6$ times daily. Invalid FFQ were defined as those which estimated daily energy intake as $2510 \mathrm{~kJ} / \mathrm{d}$ ( $<600 \mathrm{kcal} / \mathrm{d})$, or $\geq 16736 \mathrm{~kJ} / \mathrm{d}$ ( $\geq 4000 \mathrm{kcal} / \mathrm{d}$ ) for women or $17573 \mathrm{~kJ} / \mathrm{d}$ ( $\geq 4200 \mathrm{kcal} / \mathrm{d}$ ) for men, or those which had twelve or more blank items. At each exam, total protein intake was calculated as the sum of protein intake from contributions from individual line items. In addition, we separately summed protein intake from animal or plant sources. The relative validity of the FFQ for protein intake shows reasonable correlation with estimates from dietary records and urinary nitrogen ${ }^{(35,36)}$.

Protein intake $(\mathrm{g} / \mathrm{d})$ was adjusted for total energy intake using the residual method ${ }^{(36)}$. We created quartile categories of the average of the reported intake at the beginning and end of each exam interval (e.g. mean of intake reported at exams 5 and 6 , for change in outcome between exams 5 and 6). We also used average protein intake as a continuous measure (increments of $10 \mathrm{~g} / \mathrm{d}$ ). In secondary analyses, we used estimates expressed as $\mathrm{g} / \mathrm{kg}$ body weight (BW) per d, which is the unit used in dietary recommendations ${ }^{(37)}$. Other dietary factors derived from 
the FFQ included estimated intakes of energy, alcohol, carbohydrates, fats and other dietary components of the Dietary Guidelines for Americans 2010 Index (DGAI-2010) score, which was calculated as previously described ${ }^{(38)}$.

\section{Covariate assessment}

Potential confounders of the relationship between protein intake and the cardiometabolic risk factors, as well as other risk factors for these conditions, were considered as covariates, including: age (years); sex (male/female); BMI, calculated as measured weight $(\mathrm{kg})$ divided by height $(\mathrm{m})$ squared $\left(\mathrm{kg} / \mathrm{m}^{2}\right)$; regular smoking in the prior year (yes/ no); pharmacological treatment for hypertension, CVD, dyslipidaemia or diabetes (all yes/no); history of cancer (yes/no); and physical activity (score based on sum of moderate and vigorous metabolic equivalent of task (MET)-h/week). Except for age and sex, the covariate values at the beginning and end of each interval were averaged for use in analyses, to account for potential changes in these risk factors within the interval (e.g. if a participant reported smoking at exam 5, this was coded as 1 , and reported not smoking by exam 6 , which was coded 0 , the covariate value entered into the model was $0 \cdot 5$ ).

\section{Statistical approach}

Baseline (exam 5) participant characteristics adjusted for age, sex and energy intake are presented across categories of average protein intake. Tests for linear trend across increasing categories of intake were performed by assigning the median value of intake within each category and treating these as a continuous variable.

Because we sought to characterize protein's associations with average changes across time, we calculated annualized changes in the outcomes. For example, for FG, annualized change was calculated as (FG at exam $6-$ FG at exam 5)/[(exam 6 date - exam 5 date)/365.25], and so on, between each exam interval at which FG was available for a given participant. Using the averaged protein intake between intervals as the exposure, we used mixed models accounting for repeated measures within individuals to generate least-square adjusted means of changes in the outcomes. In the mixed model approach, estimates from all such exam intervals can be thought of as being averaged to produce an overall estimate of the association between the exposure and the change in the outcome over time, as the average year-over-year change in the outcomes across the study period (see online supplementary material, Supplemental Fig. 1). $P$ values for trend across quartile categories of intake were estimated using the median value in each quartile category, modelled as a continuous variable.

For primary outcomes, the initial mixed model used annualized change in outcome as the dependent variable, and the protein exposure was the primary independent variable, adjusted for age, sex, energy intake and the baseline measure of the outcome (i.e. the value at the beginning of the exam interval). Model 2 was adjusted as for model 1, plus smoking status, alcohol intake, pharmacological treatment for dyslipidaemia, CVD, hypertension or diabetes, and history of cancer. Model 2 also included annualized weight change, except for when the outcome was annualized change in weight. In model 3, we additionally adjusted for overall dietary quality, as given by averaged DGAI-2010 score. We adjusted for DGAI-2010 rather than other dietary factors or macronutrient (i.e. carbohydrate or fat) intake in models because we wanted to adjust analyses for other aspects of dietary behaviour and remain agnostic with respect to the effect of substituting one macronutrient for another. Including another macronutrient along with energy and protein in a model can be interpreted as a substitution effect for the missing macronutrient, something we sought to avoid. In analyses of animal and plant protein, an additional model (model 4) included mutual adjustment for plant and animal protein, respectively. Further adjustment for physical activity did not alter estimates (not shown). We tested for effect modification based on a priori hypotheses in the final model by assessing statistical interactions modelled as cross-product terms between protein intake as a continuous variable and age, sex, BMI, eGFR and type 2 diabetes status, and also present results of stratified analyses using predefined cut-off points of age $(<$ median $v$. $\geq$ median age of 58 years), sex (male $v$. female), BMI $\left(<25 v\right.$. $\left.\geq 25 \mathrm{~kg} / \mathrm{m}^{2}\right)$, eGFR $(<60 \quad v . \geq 60 \mathrm{ml} / \mathrm{min}$ per $1.73 \mathrm{~m}^{2}$ ) and type 2 diabetes status (yes $v$. no). Because assessment of effect modification by stratification was exploratory, we used a Bonferroni correction to the nominal $\alpha$, yielding a corrected $\alpha$ of $0 \cdot 01(0 \cdot 05 / 5$ interaction tests). Because the study was not designed to detect within-strata estimates, these may be underpowered.

Because insulin was measured using two different assays at exams 5 and 7 and because mixed models are inappropriate where only two measures are available, for the secondary outcomes of FI and HOMA-IR we used generalized linear models to perform the regression of the final measure of the outcome (exam 7) $v$. average protein intake, adjusted for the baseline measure (exam 5). Models were otherwise adjusted as for mixed model analyses described above.

Finally, in secondary analyses, we repeated the primary analyses above using average protein intake in units of $\mathrm{g} / \mathrm{kg} \mathrm{BW}$ per $\mathrm{d}$ as the exposure.

All analyses were conducted in the statistical software package SAS version 9.4. Two-tailed statistical significance was set at the 0.05 level.

\section{Results}

There were 12333 unique observations of 3066 participants with valid baseline data and at least one follow-up 
exam, for an average of four exams attended with available data (of a possible five) per participant across up to 20 years of follow-up. Baseline characteristics of the participants across quartile categories of interval-averaged protein intake are presented in Table 1 . At baseline, the mean (SD) age of the population was 54.0 (9.7) years, BMI was $27.4(4.9) \mathrm{kg} / \mathrm{m}^{2}, 53.5 \%$ were women, $23.8 \%$ were classified as obese and protein intake was $77.5(15 \cdot 8) \mathrm{g} / \mathrm{d}$. In trends from lowest to highest category of energy- adjusted protein intake, those in the highest category were more likely to be female, slightly younger, have higher average BMI, WC, FG, FI and HOMA-IR, and lower TC, HDL-C and LDL-C levels (Table 1). They were less likely to have smoked regularly in the preceding year. With increasing protein intake, intake of some dietary components tended to be higher, including energy and total, saturated and monounsaturated fat, while intake of other dietary components tended to be lower, including

Table 1 Adjusted means of baseline (1991-1995) characteristics by averaged protein intake in participants of the Framingham Heart Study Offspring cohort, USA

\begin{tabular}{|c|c|c|c|c|c|c|c|c|c|}
\hline \multirow{3}{*}{$\begin{array}{l}\text { Median }(g / d) \\
n \text { at baseline }\end{array}$} & \multicolumn{8}{|c|}{ Quartile category of average protein intake $(\mathrm{g} / \mathrm{d})$} & \multirow[b]{3}{*}{$P$ trend } \\
\hline & \multicolumn{2}{|c|}{$\begin{array}{c}\text { Q1 } \\
62 \cdot 7 \\
940 \\
\end{array}$} & \multicolumn{2}{|c|}{$\begin{array}{c}\mathrm{Q} 2 \\
73.7 \\
742 \\
\end{array}$} & \multicolumn{2}{|c|}{$\begin{array}{c}\text { Q3 } \\
82 \cdot 4 \\
650 \\
\end{array}$} & \multicolumn{2}{|c|}{$\begin{array}{c}\text { Q4 } \\
94.5 \\
734 \\
\end{array}$} & \\
\hline & Mean & SE & Mean & SE & Mean & SE & Mean & SE & \\
\hline \multicolumn{10}{|l|}{ Clinical characteristics } \\
\hline Age (years) & $55 \cdot 1$ & 0.3 & $54 \cdot 4$ & 0.3 & $54 \cdot 2$ & 0.4 & $53 \cdot 7$ & 0.4 & 0.005 \\
\hline Sex (\% female) & $40 \cdot 0$ & $2 \cdot 0$ & $55 \cdot 0$ & $2 \cdot 0$ & $59 \cdot 0$ & $2 \cdot 0$ & $62 \cdot 0$ & $2 \cdot 0$ & $<0.001$ \\
\hline BMl $\left(\mathrm{kg} / \mathrm{m}^{2}\right)$ & $26 \cdot 7$ & 0.2 & $27 \cdot 1$ & 0.2 & $27 \cdot 6$ & 0.2 & $28 \cdot 2$ & 0.2 & $<0.001$ \\
\hline Weight $(\mathrm{kg})$ & $75 \cdot 6$ & 0.5 & $76 \cdot 9$ & 0.5 & 78.4 & 0.5 & 79.9 & 0.5 & $<0.001$ \\
\hline WC (cm) & 91.5 & 0.4 & $91 \cdot 7$ & 0.5 & 93.0 & 0.5 & $94 \cdot 3$ & 0.5 & $<0.001$ \\
\hline Current smoker (\%) & $26 \cdot 0$ & $1 \cdot 0$ & $17 \cdot 0$ & $1 \cdot 0$ & $15 \cdot 0$ & 1.0 & $15 \cdot 0$ & 1.0 & $<0.001$ \\
\hline Physical activity index (MET-h/week) & $35 \cdot 3$ & 0.2 & $34 \cdot 6$ & 0.2 & $34 \cdot 6$ & 0.2 & 34.7 & 0.2 & 0.07 \\
\hline $\mathrm{TC}(\mathrm{mmol} / \mathrm{l})$ & $5 \cdot 38$ & 0.03 & $5 \cdot 29$ & 0.03 & $5 \cdot 30$ & 0.03 & $5 \cdot 24$ & 0.04 & 0.006 \\
\hline HDL-C (mmol/l) & 1.32 & 0.01 & 1.31 & 0.01 & 1.30 & 0.01 & 1.27 & 0.01 & 0.005 \\
\hline LDL-C (calculated; mmol/l) & $3 \cdot 37$ & 0.03 & 3.31 & 0.03 & $3 \cdot 33$ & 0.03 & 3.28 & 0.03 & 0.04 \\
\hline TAG $(\mathrm{mmol} / \mathrm{l})$ & 1.64 & 0.04 & 1.63 & 0.04 & 1.66 & 0.05 & 1.71 & 0.05 & 0.28 \\
\hline Treatment for dyslipidaemia (\%) & 8.0 & 1.0 & $6 \cdot 0$ & 1.0 & $7 \cdot 0$ & 1.0 & $7 \cdot 0$ & $1 \cdot 0$ & 0.59 \\
\hline SBP $(\mathrm{mmHg})$ & $126 \cdot 1$ & 0.6 & $125 \cdot 1$ & 0.6 & 125.5 & 0.6 & $126 \cdot 3$ & 0.7 & 0.73 \\
\hline $\mathrm{DBP}(\mathrm{mmHg})$ & 74.3 & 0.3 & $74 \cdot 3$ & 0.4 & 74.8 & 0.4 & $75 \cdot 1$ & 0.4 & 0.08 \\
\hline Treatment for hypertension (\%) & $17 \cdot 0$ & $1 \cdot 0$ & $17 \cdot 0$ & 1.0 & $17 \cdot 0$ & 1.0 & $19 \cdot 0$ & 1.0 & 0.22 \\
\hline Treatment for CVD (\%) & $25 \cdot 0$ & 1.0 & $24 \cdot 0$ & 1.0 & $25 \cdot 0$ & $2 \cdot 0$ & $27 \cdot 0$ & $2 \cdot 0$ & 0.33 \\
\hline $\mathrm{FG}(\mathrm{mmol} / \mathrm{l})$ & 5.43 & 0.05 & $5 \cdot 49$ & 0.05 & $5 \cdot 60$ & 0.05 & $5 \cdot 76$ & 0.05 & $<0.001$ \\
\hline $\mathrm{FI}(\mathrm{mU} / \mathrm{ml})$ & $29 \cdot 8$ & 0.7 & $29 \cdot 7$ & 0.7 & 31.6 & 0.7 & $32 \cdot 2$ & 0.7 & 0.007 \\
\hline HOMA-IR & 7.5 & 0.3 & 7.5 & 0.4 & 8.4 & 0.4 & 8.9 & 0.4 & 0.001 \\
\hline eGFR $\left(\mathrm{ml} / \mathrm{min}\right.$ per $\left.1.73 \mathrm{~m}^{2}\right)$ & 89.4 & 0.6 & $88 \cdot 7$ & 0.7 & 88.9 & 0.7 & 89.9 & 0.7 & 0.60 \\
\hline Treatment for diabetes (\%) & $2 \cdot 0$ & 1.0 & 2.0 & 1.0 & 4.0 & 1.0 & $5 \cdot 0$ & 1.0 & $<0.001$ \\
\hline History of cancer (\%) & $16 \cdot 0$ & 1.0 & $16 \cdot 0$ & 1.0 & $18 \cdot 0$ & 1.0 & $15 \cdot 0$ & 1.0 & 0.81 \\
\hline \multicolumn{10}{|l|}{ Dietary characteristics } \\
\hline Energy $(\mathrm{kJ} / \mathrm{d})$ & 8142 & 88 & 7393 & 88 & 7410 & 92 & 8489 & 96 & 0.02 \\
\hline Energy $(\mathrm{kcal} / \mathrm{d})$ & 1946 & 21 & 1767 & 21 & 1771 & 22 & 2029 & 23 & 0.02 \\
\hline DGAI-2010 score & 54.7 & 0.4 & $60 \cdot 0$ & 0.4 & $63 \cdot 0$ & 0.4 & $63 \cdot 3$ & 0.4 & $<0.001$ \\
\hline Carbohydrates $(\mathrm{g} / \mathrm{d})$ & 253.9 & 1.4 & $242 \cdot 8$ & 1.4 & $232 \cdot 8$ & 1.5 & $219 \cdot 1$ & 1.5 & $<0.001$ \\
\hline Fibre $(g / d)$ & $16 \cdot 6$ & 0.2 & $18 \cdot 2$ & 0.2 & $18 \cdot 6$ & 0.2 & $18 \cdot 9$ & $0 \cdot 2$ & $<0.001$ \\
\hline Glycaemic index & $55 \cdot 3$ & 0.1 & $55 \cdot 2$ & 0.1 & 54.4 & 0.1 & 53.6 & 0.1 & $<0.001$ \\
\hline Glycaemic load & 13939 & 89 & 13320 & 92 & 12593 & 94 & 11672 & 98 & $<0.001$ \\
\hline Fat $(g / d)$ & $59 \cdot 8$ & 0.5 & $63 \cdot 1$ & 0.5 & $63 \cdot 7$ & 0.5 & $65 \cdot 0$ & 0.5 & $<0.001$ \\
\hline SFA $(g / d)$ & $20 \cdot 9$ & 0.2 & $21 \cdot 8$ & 0.2 & $22 \cdot 0$ & 0.2 & $22 \cdot 7$ & 0.2 & $<0.001$ \\
\hline PUFA (g/d) & 11.9 & 0.1 & $12 \cdot 2$ & 0.1 & $12 \cdot 4$ & 0.1 & $12 \cdot 1$ & 0.1 & 0.09 \\
\hline MUFA $(g / d)$ & $22 \cdot 1$ & 0.2 & 23.5 & 0.2 & 23.6 & 0.2 & $24 \cdot 0$ & 0.2 & $<0.001$ \\
\hline Protein (g/d) & $60 \cdot 0$ & 0.3 & $73 \cdot 7$ & 0.3 & 82.5 & 0.3 & $97 \cdot 8$ & 0.3 & $<0.001$ \\
\hline Animal protein $(\mathrm{g} / \mathrm{d})$ & $37 \cdot 1$ & 0.3 & $49 \cdot 1$ & 0.3 & $57 \cdot 8$ & 0.4 & 74.0 & 0.4 & $<0.001$ \\
\hline Plant protein (g/d) & $22 \cdot 9$ & 0.2 & 24.5 & 0.2 & $24 \cdot 7$ & 0.2 & $23 \cdot 8$ & 0.2 & $<0.001$ \\
\hline Protein ( $\mathrm{g} / \mathrm{kg}$ BW per d) & 0.84 & 0.01 & 1.00 & 0.01 & $1 \cdot 10$ & 0.01 & 1.28 & 0.01 & $<0.001$ \\
\hline Protein (\% of energy) & $13 \cdot 1$ & 0.1 & $15 \cdot 9$ & 0.1 & $18 \cdot 1$ & 0.1 & $21 \cdot 0$ & 0.1 & $<0.001$ \\
\hline Meets protein $\mathrm{RDA}^{*}(\%)$ & 50.0 & 1.0 & 81.0 & 1.0 & 91.0 & 1.0 & 97.0 & 1.0 & $<0.001$ \\
\hline
\end{tabular}

WC, waist circumference; MET, metabolic equivalent of task; TC, total cholesterol; HDL-C, HDL-cholesterol; LDL-C, LDL-cholesterol; SBP, systolic blood pressure; DBP, diastolic blood pressure; FG, fasting plasma glucose; FI, fasting plasma insulin; HOMA-IR, homeostatic model assessment of insulin resistance; eGFR, estimated glomerular filtration rate; DGAI-2010, Dietary Guidelines for Americans 2010 Index; BW, body weight.

${ }^{*} \mathrm{RDA}$ in the USA ${ }^{(37)}$. 
carbohydrates, fibre and polyunsaturated fat. Protein intake as a percentage contribution to total energy intake across exams was relatively stable from exams 5 through 9 , at $16 \cdot 8,17 \cdot 1,17 \cdot 3,18 \cdot 0$ and $16 \cdot 7 \%$, respectively.

Overall, $21.5 \%$ of participants at baseline were not meeting the RDA of $0.8 \mathrm{~g}$ protein $/ \mathrm{kg} \mathrm{BW}$ per $\mathrm{d}$ (see online supplementary material, Supplemental Table 1). However, when examined in BMI categories, only $6 \cdot 2 \%$ of normal weight $\left(<25 \mathrm{~kg} / \mathrm{m}^{2}\right)$ participants, compared with $20.6 \%$ of overweight $\left(25-<30 \mathrm{~kg} / \mathrm{m}^{2}\right)$ and $45.4 \%$ of obese $\left(\geq 30 \mathrm{~kg} / \mathrm{m}^{2}\right)$ participants, were not meeting the RDA for protein $(P<0 \cdot 001)$. Protein intake expressed in $\mathrm{g} / \mathrm{d}$ or as a percentage of energy was higher in higher BMI categories, whereas protein intake expressed in $\mathrm{g} / \mathrm{kg} \mathrm{BW}$ per $\mathrm{d}$ was lower in higher BMI categories. This trend held across all exams.

Across all participants, annualized mean changes in outcomes were as expected with ageing and treatment. Estimates adjusted for age, sex, weight change (except the outcome of change in weight), alcohol intake, smoking, treatment for any one of CVD, dyslipidaemia, diabetes or hypertension, and history of cancer, indicated mean (sE) annualized declines in DBP $(-0.18(0.03) \mathrm{mmHg})$, TC $(-0.033(0.002) \mathrm{mmol} / \mathrm{l})$, LDL-C (-0.039 (0.001) $\mathrm{mmol} / \mathrm{l})$, TAG (-0.021 (0.001) mmol/l) and eGFR (-0.94 (0.03) ml/ min per $\left.1.73 \mathrm{~m}^{2}\right)$ and annualized increases in mean weight $(0.08 \quad(0.01) \mathrm{kg}), \quad$ WC $\quad(0.52 \quad(0.01) \mathrm{cm}), \quad$ SBP $\quad(0.18$ $(0.03) \mathrm{mmHg}), \mathrm{FG}(0.020(0.002) \mathrm{mmol} / \mathrm{l})$ and HDL-C $(0 \cdot 014(0 \cdot 001) \mathrm{mmol} / \mathrm{l})$.

\section{Quartile categories of average protein intake and annualized changes in outcomes}

Across quartile categories of increasing average protein intake expressed in $\mathrm{g} / \mathrm{d}$, adjusted for age, sex, energy intake and the baseline measure of the outcome of interest (model 1), there were statistically significant associations with beneficial annualized changes in SBP, DBP, TC and LDL-C, and deleterious annualized changes in FG (Table 2). After further adjusting for cardiometabolic risks/ treatments and other dietary characteristics (model 3), only relationships between protein intake and SBP and FG remained statistically significant, and changes in eGFR became statistically significant (mean (SE) annualized change in the lowest $v$. highest quartile category of protein intake, respectively: for SBP, $0.34(0.06) \quad v$. 0.04 $(0.06) \mathrm{mmHg}, P$ trend $=0.001$; for FG, 0.013 (0.004) $v$. $0.028(0.004) \mathrm{mmol} / \mathrm{l}, P$ trend $=0.004$; and for eGFR, -1.03 $(0.06) v .-0.87(0.05) \mathrm{ml} / \mathrm{min} / 1.73 \mathrm{~m}^{2}, P$ trend $\left.=0.046\right)$. Protein intake expressed as a continuous linear measure (i.e. per $10 \mathrm{~g} / \mathrm{d}$ ) was generally consistent with the categorical approach (Table 2).

Assessment of effect modification (interaction tests) of total protein by age, BMI, sex, eGFR and type 2 diabetes status indicated that the only significant interactions were between protein and diabetes status on the outcomes of
FG and TAG; stratifying by diabetes status suggested unfavourable changes in FG with higher protein intake only in those with type 2 diabetes and favourable changes in TAG in those without type 2 diabetes (see online supplementary material, Supplemental Table 2).

Protein from animal and plant sources had differential associations with changes in outcomes (Table 3). In models adjusted for DGAI-2010 score (model 3), protein from animal sources was unfavourably associated with changes in FG and WC, and favourably associated with changes in SBP. However, the association with WC was no longer significant after adjusting for plant protein. Plant protein was favourably associated with FG and WC; however, associations with FG were no longer significant after adjusting for animal protein. Of note, there was only a $\sim 10 \mathrm{~g} / \mathrm{d}$ difference between those with high and low plant protein intake, whereas the distribution of animal protein intake was much wider, at $\sim 30 \mathrm{~g} / \mathrm{d}$ between highest and lowest quartiles. Pearson correlations between animal and vegetable protein ranged from $r=-0.22$ to $-0 \cdot 32$, across exams.

In 2422 participants with both exam 5 and 7 measures of the secondary outcomes of FI and HOMA-IR, there were no significant associations with total, animal or plant protein intake in the fully adjusted model (see online supplementary material, Supplemental Table 3).

\section{Secondary analyses of protein expressed in $\mathrm{g} / \mathrm{kg}$ body weight per $d$ and annualized changes in outcomes}

When protein intake was expressed in terms of $\mathrm{g} / \mathrm{kg} \mathrm{BW}$ per $d$, there were substantially different results from those when protein intake was expressed in terms of $\mathrm{g} / \mathrm{d}$ with respect to the annualized changes in the outcomes of interest. In fully adjusted models, protein intake was statistically significantly associated with beneficial annual changes in eGFR, FG, HDL-C, TAG, WC and weight, and deleterious annual changes in TC only (see online supplementary material, Supplemental Table 4). Because protein intake expressed in $\mathrm{g} / \mathrm{kg} \mathrm{BW}$ per $\mathrm{d}$ may be confounded by BMI, we stratified this secondary analysis by BMI category (Supplemental Table 5). Results suggest that associations were different depending on BMI category for FG, HDL-C, TC and SBP, and that all BMI categories benefited from higher protein in terms of changes in WC and weight.

\section{Discussion}

In the present analysis, we observed that higher protein intake was favourably associated with annualized changes in SBP and kidney function, as assessed by eGFR, and unfavourably associated with annualized changes in FG. Protein from animal sources was unfavourably associated 
Table 2 Adjusted mean annualized changes in outcomes by averaged protein intake, expressed in units of $\mathrm{g} / \mathrm{d}$, in participants of the Framingham Heart Study Offspring cohort, USA (1991-2004)

\begin{tabular}{|c|c|c|c|c|c|c|c|c|c|c|c|c|c|}
\hline \multirow{3}{*}{$\begin{array}{l}\text { Annualized } \\
\text { change in... }\end{array}$} & \multirow[b]{3}{*}{ Model $^{*}$} & \multicolumn{8}{|c|}{$\begin{array}{c}\text { Adjusted mean annualized change (SE) per quartile category of } \\
\text { averaged protein intake }(\mathrm{g} / \mathrm{d}) \\
\end{array}$} & \multirow[b]{3}{*}{$P$ trend } & \multicolumn{2}{|c|}{$\begin{array}{c}\beta(\mathrm{SE}) \text { per } 10 \mathrm{~g} / \mathrm{d} \\
\text { averaged protein } \\
\text { intake }\end{array}$} & \multirow{3}{*}{$\begin{array}{c}P \\
\text { continuous }\end{array}$} \\
\hline & & \multicolumn{2}{|c|}{$64 \cdot 4$} & \multicolumn{2}{|c|}{74.6} & \multicolumn{2}{|c|}{$82 \cdot 5$} & \multicolumn{2}{|c|}{$93 \cdot 3$} & & \multirow[b]{2}{*}{$\beta$} & \multirow[b]{2}{*}{ SE } & \\
\hline & & Mean & SE & Mean & SE & Mean & $\mathrm{SE}$ & Mean & SE & & & & \\
\hline \multirow[t]{3}{*}{$\mathrm{DBP}(\mathrm{mmHg})$} & 1 & -0.09 & 0.04 & -0.17 & 0.03 & -0.22 & 0.03 & -0.24 & 0.03 & 0.002 & -0.046 & 0.013 & 0.0004 \\
\hline & 2 & -0.13 & 0.04 & -0.18 & 0.03 & -0.19 & 0.03 & -0.20 & 0.03 & 0.14 & -0.023 & 0.012 & 0.06 \\
\hline & 3 & -0.14 & 0.04 & -0.19 & 0.03 & -0.19 & 0.03 & -0.19 & 0.03 & 0.33 & -0.018 & 0.013 & 0.17 \\
\hline eGFR $(\mathrm{ml} / \mathrm{min}$ per & 1 & -0.94 & 0.06 & -0.99 & 0.05 & -0.95 & 0.05 & -0.97 & 0.05 & 0.91 & -0.001 & 0.021 & 0.96 \\
\hline \multirow[t]{2}{*}{$\left.1.73 \mathrm{~m}^{2}\right)$} & 2 & -1.03 & 0.06 & -0.98 & 0.05 & -0.91 & 0.05 & -0.88 & 0.05 & 0.03 & 0.050 & 0.021 & 0.02 \\
\hline & 3 & -1.02 & 0.06 & -0.98 & 0.05 & -0.91 & 0.05 & -0.87 & 0.05 & 0.046 & 0.048 & 0.022 & 0.03 \\
\hline \multirow[t]{3}{*}{$\mathrm{FG}(\mathrm{mmol} / \mathrm{l})$} & 1 & 0.011 & 0.004 & 0.013 & 0.004 & 0.021 & 0.004 & 0.026 & 0.004 & 0.002 & 0.0041 & 0.0014 & 0.004 \\
\hline & 2 & 0.015 & 0.004 & 0.014 & 0.004 & 0.023 & 0.004 & 0.026 & 0.004 & 0.012 & 0.0031 & 0.0015 & 0.04 \\
\hline & 3 & 0.013 & 0.004 & 0.014 & 0.004 & 0.023 & 0.004 & 0.028 & 0.004 & 0.004 & 0.0038 & 0.0016 & 0.02 \\
\hline \multirow[t]{3}{*}{ HDL-C (mmol/l) } & 1 & 0.015 & 0.001 & 0.013 & 0.001 & 0.016 & 0.001 & 0.014 & 0.001 & 0.65 & 0.0001 & 0.0004 & 0.87 \\
\hline & 2 & 0.013 & 0.001 & 0.013 & 0.001 & 0.016 & 0.001 & 0.014 & 0.001 & 0.34 & 0.0006 & 0.0004 & $0 \cdot 11$ \\
\hline & 3 & 0.014 & 0.001 & 0.013 & 0.001 & 0.015 & 0.001 & 0.014 & 0.001 & 0.97 & 0.0002 & 0.0004 & 0.51 \\
\hline \multirow[t]{3}{*}{ LDL-C (mmol/l) } & 1 & -0.035 & 0.003 & -0.042 & 0.003 & -0.046 & 0.003 & -0.048 & 0.003 & 0.001 & -0.0032 & 0.0010 & 0.002 \\
\hline & 2 & -0.037 & 0.003 & -0.040 & 0.002 & -0.041 & 0.002 & -0.041 & 0.002 & 0.28 & -0.0009 & 0.0010 & 0.37 \\
\hline & 3 & -0.037 & 0.003 & -0.040 & 0.003 & -0.041 & 0.002 & -0.041 & 0.002 & 0.34 & -0.0007 & 0.0010 & 0.48 \\
\hline \multirow[t]{3}{*}{$\mathrm{SBP}(\mathrm{mmHg})$} & 1 & 0.36 & 0.06 & 0.19 & 0.06 & 0.14 & 0.05 & 0.00 & 0.05 & $<0.0001$ & $-0 \cdot 102$ & 0.021 & $<0.0001$ \\
\hline & 2 & 0.32 & 0.06 & 0.20 & 0.06 & 0.19 & 0.05 & 0.05 & 0.05 & 0.002 & -0.076 & 0.022 & 0.001 \\
\hline & 3 & 0.34 & 0.06 & 0.20 & 0.06 & $0 \cdot 18$ & 0.05 & 0.04 & 0.06 & 0.001 & -0.084 & 0.023 & 0.0003 \\
\hline \multirow[t]{3}{*}{ TC $(\mathrm{mmol} / \mathrm{l})$} & 1 & -0.024 & 0.003 & -0.036 & 0.003 & -0.038 & 0.003 & -0.043 & 0.003 & $<0.001$ & -0.0046 & 0.0012 & 0.0001 \\
\hline & 2 & -0.031 & 0.003 & -0.035 & 0.003 & -0.032 & 0.003 & -0.033 & 0.003 & 0.75 & -0.0001 & 0.0011 & 0.95 \\
\hline & 3 & -0.031 & 0.003 & -0.034 & 0.003 & -0.032 & 0.003 & -0.033 & 0.003 & 0.78 & 0.0001 & 0.0012 & 0.97 \\
\hline \multirow[t]{3}{*}{ TAG (mmol/l) } & 1 & -0.017 & 0.003 & -0.023 & 0.002 & -0.022 & 0.002 & -0.023 & 0.002 & $0 \cdot 12$ & -0.0017 & 0.0009 & 0.049 \\
\hline & 2 & -0.016 & 0.003 & -0.023 & 0.002 & -0.021 & 0.002 & -0.024 & 0.002 & 0.07 & -0.0019 & 0.0009 & 0.03 \\
\hline & 3 & -0.018 & 0.003 & -0.024 & 0.002 & -0.021 & 0.002 & -0.023 & 0.002 & 0.42 & -0.0011 & 0.0009 & 0.23 \\
\hline \multirow[t]{3}{*}{ WC (cm) } & 1 & 0.51 & 0.03 & 0.55 & 0.03 & 0.53 & 0.02 & 0.51 & 0.02 & 0.91 & -0.004 & 0.010 & 0.70 \\
\hline & 2 & 0.52 & 0.02 & 0.53 & 0.02 & 0.53 & 0.01 & 0.52 & 0.01 & 0.77 & -0.002 & 0.006 & 0.77 \\
\hline & 3 & 0.50 & 0.02 & 0.53 & 0.02 & 0.53 & 0.01 & 0.53 & 0.01 & 0.41 & 0.005 & 0.006 & 0.42 \\
\hline \multirow[t]{3}{*}{ Weight (kg) } & 1 & 0.05 & 0.02 & 0.09 & 0.02 & 0.06 & 0.02 & 0.09 & 0.02 & 0.30 & 0.003 & 0.009 & 0.69 \\
\hline & 2 & 0.05 & 0.02 & 0.09 & 0.02 & 0.07 & 0.02 & 0.10 & 0.02 & 0.14 & 0.007 & 0.009 & 0.41 \\
\hline & 3 & 0.05 & 0.03 & 0.09 & 0.02 & 0.07 & 0.02 & $0 \cdot 10$ & 0.02 & 0.25 & 0.004 & 0.009 & 0.63 \\
\hline
\end{tabular}

DBP, diastolic blood pressure; eGFR, estimated glomerular filtration rate; FG, fasting plasma glucose; HDL-C, HDL-cholesterol; LDL-C, LDL-cholesterol; SBP, systolic blood pressure; TC, total cholesterol; WC, waist circumference.

*Model 1 was adjusted for age, sex, energy intake and the baseline measure of the outcome (i.e. the value at the beginning of the exam interval). Model 2 was adjusted as for model 1, plus smoking status, alcohol intake, pharmacological treatment for dyslipidaemia, CVD, hypertension or diabetes, and history of cancer. Model 2 also included change in weight, except for when the outcome was change in weight. In model 3, we additionally adjusted for the Dietary Guidelines for Americans 2010 Index score.

with changes in FG and favourably associated with changes in SBP, while plant protein was favourably associated with WC.

Two recent meta-analyses ${ }^{(39,40)}$ of protein intake in observational and/or experimental studies suggest that higher protein intake, particularly when replacing carbohydrate intake, may favourably if modestly impact blood pressure and risk of hypertension. A recently published study of plant and animal protein intake in elderly Dutch participants observed that those with the highest plant protein intake had average 5-year declines in mean $(95 \%$ CI) SBP $(-2.9(-5 \cdot 6,-0 \cdot 2) \mathrm{mmHg})$ and DBP $(-1.7(-3.2$, $-0 \cdot 2) \mathrm{mmHg}$ ), compared with those with the lowest intake, and no associations were observed for animal protein ${ }^{(25)}$. In a prior study conducted in earlier exams in a subsample of the Framingham Offspring cohort, total protein intake derived from $3 \mathrm{~d}$ food records (as well as both animal and plant protein intake) was favourably associated with SBP and DBP, as well as incident hypertension, across 11 years of follow-up ${ }^{(26)}$.

We observed a strong relationship between total protein intake and annualized changes in FG, driven by animal protein intake. This relationship is plausibly supported by other experimental and observational literature regarding protein intake and type 2 diabetes risk. For example, results from the pan-European Diet, Obesity and Genes (DiOGenes) study of protein intake (and glycaemic index) on weight maintenance following weight loss indicated favourable changes in fasting glucose with higher protein intake over the weight-maintenance period ${ }^{(41)}$. A metaanalysis of eleven longitudinal cohorts found that total and animal protein intakes were associated with higher risk of incident type 2 diabetes, while plant protein intake was associated with modestly lower risk of diabetes in women only $^{(21)}$. However, a 2013 meta-analysis $^{(42)}$ and other evidence from trials of overfeeding ${ }^{(43)}$, restricted $^{(9,44)}$ or 
Table 3 Adjusted mean annualized changes in outcomes by averaged animal and plant protein intake, expressed in units of $\mathrm{g} / \mathrm{d}$, in participants of the Framingham Heart Study Offspring cohort, USA (1991-2004)

Animal protein

\begin{tabular}{|c|c|c|c|c|c|c|c|c|c|c|c|c|c|}
\hline \multirow[b]{4}{*}{ Annualized change in... } & \multirow[b]{4}{*}{ Model* $^{*}$} & \multicolumn{12}{|c|}{ Animal protein } \\
\hline & & \multicolumn{8}{|c|}{$\begin{array}{c}\text { Adjusted mean annualized change (SE) per quartile category of } \\
\text { averaged intake }(\mathrm{g} / \mathrm{d})\end{array}$} & \multirow[b]{3}{*}{$P$ trend } & \multicolumn{2}{|c|}{$\beta$ (SE) per $10 \mathrm{~g} / \mathrm{d}$} & \multirow{3}{*}{$\stackrel{P}{\text { continuous }}$} \\
\hline & & \multicolumn{2}{|c|}{39.9} & \multicolumn{2}{|c|}{$50 \cdot 0$} & \multicolumn{2}{|c|}{$58 \cdot 0$} & \multicolumn{2}{|c|}{$69 \cdot 6$} & & \multirow[b]{2}{*}{$\beta$} & \multirow[b]{2}{*}{ SE } & \\
\hline & & Mean & SE & Mean & SE & Mean & SE & Mean & $\mathrm{SE}$ & & & & \\
\hline \multirow[t]{4}{*}{$\mathrm{DBP}(\mathrm{mmHg})$} & 1 & -0.121 & 0.036 & -0.186 & 0.034 & -0.173 & 0.033 & -0.259 & 0.033 & 0.01 & -0.0454 & 0.0125 & $<0.001$ \\
\hline & 2 & -0.147 & 0.034 & -0.187 & 0.032 & -0.162 & 0.031 & -0.211 & 0.031 & 0.24 & -0.0266 & 0.0119 & 0.03 \\
\hline & 3 & -0.152 & 0.034 & -0.190 & 0.032 & -0.157 & 0.031 & -0.205 & 0.031 & 0.37 & -0.0242 & 0.0120 & 0.04 \\
\hline & 4 & -0.170 & 0.036 & -0.195 & 0.032 & -0.154 & 0.031 & -0.193 & 0.032 & 0.81 & -0.0180 & 0.0131 & 0.17 \\
\hline \multirow{4}{*}{$\begin{array}{l}\text { eGFR }(\mathrm{ml} / \mathrm{min} \text { per } \\
\left.1.73 \mathrm{~m}^{2}\right)\end{array}$} & 1 & -0.955 & 0.060 & -0.989 & 0.053 & -0.894 & 0.051 & -1.020 & 0.053 & 0.56 & 0.0098 & 0.0207 & 0.64 \\
\hline & 2 & -1.012 & 0.058 & -0.977 & 0.052 & -0.876 & 0.050 & -0.933 & 0.052 & 0.22 & 0.0478 & 0.0203 & 0.02 \\
\hline & 3 & -1.009 & 0.058 & -0.970 & 0.052 & -0.880 & 0.050 & -0.928 & 0.052 & 0.23 & 0.0469 & 0.0203 & 0.02 \\
\hline & 4 & -1.003 & 0.061 & -0.968 & 0.052 & -0.881 & 0.050 & -0.932 & 0.053 & 0.32 & 0.0478 & 0.0219 & 0.03 \\
\hline \multirow[t]{4}{*}{$\mathrm{FG}(\mathrm{mmol} / \mathrm{l})$} & 1 & 0.009 & 0.004 & 0.013 & 0.004 & 0.022 & 0.004 & 0.028 & 0.004 & $<0.001$ & 0.0055 & 0.0014 & $<0.001$ \\
\hline & 2 & 0.012 & 0.004 & 0.014 & 0.004 & 0.024 & 0.004 & 0.027 & 0.004 & 0.001 & 0.0042 & 0.0014 & 0.003 \\
\hline & 3 & 0.011 & 0.004 & 0.015 & 0.004 & 0.025 & 0.004 & 0.028 & 0.004 & 0.001 & 0.0044 & 0.0014 & 0.002 \\
\hline & 4 & 0.012 & 0.004 & 0.015 & 0.004 & 0.025 & 0.004 & 0.027 & 0.004 & 0.004 & 0.0037 & 0.0016 & 0.02 \\
\hline \multirow[t]{4}{*}{ HDL-C (mmol/l) } & 1 & 0.014 & 0.001 & 0.016 & 0.001 & 0.014 & 0.001 & 0.013 & 0.001 & 0.27 & -0.0003 & 0.0003 & 0.34 \\
\hline & 2 & 0.013 & 0.001 & 0.015 & 0.001 & 0.014 & 0.001 & 0.014 & 0.001 & 0.89 & 0.0000 & 0.0003 & 0.92 \\
\hline & 3 & 0.014 & 0.001 & 0.015 & 0.001 & 0.014 & 0.001 & 0.013 & 0.001 & 0.52 & -0.0001 & 0.0003 & 0.74 \\
\hline & 4 & 0.013 & 0.001 & 0.015 & 0.001 & 0.014 & 0.001 & 0.014 & 0.001 & 0.75 & 0.0003 & 0.0004 & 0.46 \\
\hline \multirow[t]{4}{*}{ LDL-C (mmol/l) } & 1 & -0.038 & 0.003 & -0.040 & 0.003 & -0.048 & 0.003 & -0.046 & 0.003 & 0.01 & -0.0024 & 0.0010 & 0.02 \\
\hline & 2 & -0.038 & 0.003 & -0.038 & 0.002 & -0.044 & 0.002 & -0.039 & 0.002 & 0.48 & -0.0004 & 0.0009 & 0.66 \\
\hline & 3 & -0.039 & 0.003 & -0.037 & 0.002 & -0.044 & 0.002 & -0.039 & 0.002 & 0.57 & -0.0002 & 0.0009 & 0.79 \\
\hline & 4 & -0.037 & 0.003 & -0.037 & 0.003 & -0.045 & 0.002 & -0.040 & 0.002 & 0.31 & -0.0007 & 0.0010 & 0.46 \\
\hline \multirow[t]{4}{*}{$\mathrm{SBP}(\mathrm{mmHg})$} & 1 & 0.305 & 0.060 & 0.191 & 0.057 & 0.174 & 0.055 & -0.014 & 0.054 & $<0.001$ & -0.0900 & 0.0208 & $<0.001$ \\
\hline & 2 & 0.286 & 0.060 & 0.211 & 0.057 & 0.214 & 0.055 & 0.047 & 0.054 & 0.003 & -0.0722 & 0.0209 & 0.001 \\
\hline & 3 & 0.293 & 0.060 & 0.204 & 0.057 & 0.209 & 0.055 & 0.047 & 0.055 & 0.003 & -0.0732 & 0.0212 & 0.001 \\
\hline & 4 & 0.312 & 0.063 & 0.208 & 0.057 & 0.205 & 0.055 & 0.035 & 0.056 & 0.002 & -0.0855 & 0.0230 & $<0.001$ \\
\hline \multirow[t]{4}{*}{$\mathrm{TC}(\mathrm{mmol} / \mathrm{l})$} & 1 & -0.028 & 0.003 & -0.031 & 0.003 & -0.041 & 0.003 & -0.041 & 0.003 & 0.001 & -0.0036 & 0.0012 & 0.003 \\
\hline & 2 & -0.032 & 0.003 & -0.029 & 0.003 & -0.038 & 0.003 & -0.032 & 0.003 & 0.70 & -0.0001 & 0.0011 & 0.96 \\
\hline & 3 & -0.032 & 0.003 & -0.029 & 0.003 & -0.038 & 0.003 & -0.031 & 0.003 & 0.75 & 0.0001 & 0.0011 & 0.95 \\
\hline & 4 & -0.032 & 0.003 & -0.029 & 0.003 & -0.038 & 0.003 & -0.031 & 0.003 & 0.72 & 0.0000 & 0.0012 & 0.97 \\
\hline TAG (mmol/l) & 1 & -0.019 & 0.003 & -0.025 & 0.002 & -0.021 & 0.002 & -0.021 & 0.002 & 0.75 & -0.0006 & 0.0009 & 0.47 \\
\hline & 2 & -0.018 & 0.003 & -0.025 & 0.002 & -0.021 & 0.002 & -0.021 & 0.002 & 0.65 & -0.0009 & 0.0009 & 0.26 \\
\hline & 3 & -0.019 & 0.003 & -0.025 & 0.002 & -0.020 & 0.002 & -0.021 & 0.002 & 0.99 & -0.0006 & 0.0009 & 0.50 \\
\hline & 4 & -0.018 & 0.003 & -0.025 & 0.002 & -0.020 & 0.002 & -0.022 & 0.002 & 0.65 & -0.0012 & 0.0009 & 0.22 \\
\hline WC (cm) & 1 & 0.482 & 0.027 & 0.521 & 0.026 & 0.538 & 0.025 & 0.550 & 0.024 & 0.06 & 0.0216 & 0.0094 & 0.02 \\
\hline & 2 & 0.490 & 0.016 & 0.536 & 0.016 & 0.528 & 0.015 & 0.541 & 0.014 & 0.04 & 0.0109 & 0.0055 & 0.048 \\
\hline & 3 & 0.481 & 0.016 & 0.538 & 0.016 & 0.531 & 0.015 & 0.548 & 0.014 & 0.01 & 0.0144 & 0.0056 & 0.01 \\
\hline & 4 & 0.504 & 0.017 & 0.544 & 0.016 & 0.528 & 0.015 & 0.535 & 0.015 & 0.34 & 0.0042 & 0.0061 & 0.49 \\
\hline Weight (kg) & 1 & 0.061 & 0.024 & 0.068 & 0.023 & 0.083 & 0.022 & 0.086 & 0.022 & 0.39 & 0.0122 & 0.0084 & 0.15 \\
\hline & 2 & 0.060 & 0.024 & 0.070 & 0.023 & 0.085 & 0.022 & 0.092 & 0.022 & 0.28 & 0.0141 & 0.0085 & $0 \cdot 10$ \\
\hline & 3 & 0.060 & 0.024 & 0.068 & 0.023 & 0.087 & 0.022 & 0.092 & 0.022 & 0.29 & 0.0144 & 0.0086 & 0.09 \\
\hline & 4 & 0.079 & 0.025 & 0.072 & 0.023 & 0.083 & 0.022 & 0.078 & 0.023 & 0.95 & 0.0058 & 0.0094 & 0.54 \\
\hline
\end{tabular}

Plant protein

Adjusted mean annualized change (SE) per quartile category of averaged intake $(\mathrm{g} / \mathrm{d})$

$\beta$ (SE) per $10 \mathrm{~g} / \mathrm{d}$

\begin{tabular}{|c|c|c|c|c|c|c|c|c|c|c|c|c|c|}
\hline \multirow[b]{3}{*}{ Annualized change in... } & \multirow[b]{3}{*}{ Model $^{\star}$} & & \multirow[b]{3}{*}{$P$ trend } & \multicolumn{2}{|c|}{$\cos ^{2}$} & \multirow{3}{*}{$\begin{array}{c}P \\
\text { continuous }\end{array}$} \\
\hline & & \multicolumn{2}{|c|}{$19 \cdot 1$} & \multicolumn{2}{|c|}{$22 \cdot 7$} & \multicolumn{2}{|c|}{$25 \cdot 3$} & \multicolumn{2}{|c|}{29.6} & & \multirow[b]{2}{*}{$\beta$} & \multirow[b]{2}{*}{ SE } & \\
\hline & & Mean & SE & Mean & SE & Mean & SE & Mean & SE & & & & \\
\hline \multirow[t]{4}{*}{$\mathrm{DBP}(\mathrm{mmHg})$} & 1 & -0.230 & 0.036 & -0.114 & 0.034 & -0.192 & 0.033 & -0.216 & 0.032 & 0.69 & 0.0105 & 0.0311 & 0.74 \\
\hline & 2 & -0.228 & 0.034 & -0.117 & 0.032 & -0.180 & 0.032 & -0.189 & 0.031 & 0.84 & 0.0350 & 0.0298 & 0.24 \\
\hline & 3 & -0.250 & 0.037 & -0.121 & 0.033 & -0.169 & 0.032 & -0.173 & 0.032 & 0.37 & 0.0619 & 0.0326 & 0.06 \\
\hline & 4 & -0.233 & 0.038 & -0.115 & 0.033 & -0.171 & 0.032 & -0.189 & 0.033 & 0.83 & 0.0429 & 0.0354 & 0.23 \\
\hline eGFR $(\mathrm{ml} / \mathrm{min}$ per & 1 & -0.863 & 0.059 & -0.973 & 0.054 & -0.976 & 0.052 & -1.030 & 0.052 & 0.04 & -0.0646 & 0.0510 & 0.20 \\
\hline \multirow[t]{3}{*}{$\left.1.73 \mathrm{~m}^{2}\right)$} & 2 & -0.894 & 0.058 & -0.956 & 0.052 & -0.945 & 0.051 & -0.981 & 0.051 & 0.30 & -0.0130 & 0.0503 & 0.80 \\
\hline & 3 & -0.861 & 0.061 & -0.941 & 0.052 & -0.960 & 0.051 & -0.999 & 0.053 & $0 \cdot 11$ & -0.0421 & 0.0539 & 0.43 \\
\hline & 4 & -0.889 & 0.062 & -0.952 & 0.053 & -0.958 & 0.051 & -0.975 & 0.054 & 0.38 & 0.0064 & 0.0583 & 0.91 \\
\hline \multirow[t]{2}{*}{$\mathrm{FG}(\mathrm{mmol} / \mathrm{l})$} & 1 & 0.024 & 0.004 & 0.024 & 0.004 & 0.017 & 0.004 & 0.011 & 0.003 & 0.01 & -0.0094 & 0.0034 & 0.01 \\
\hline & 2 & 0.025 & 0.004 & 0.024 & 0.004 & 0.019 & 0.004 & 0.012 & 0.004 & 0.01 & -0.0083 & 0.0035 & 0.02 \\
\hline
\end{tabular}




\begin{tabular}{|c|c|c|c|c|c|c|c|c|c|c|c|c|c|}
\hline \multirow[b]{4}{*}{ Annualized change in... } & \multirow[b]{4}{*}{ Model $^{*}$} & \multicolumn{12}{|c|}{ Plant protein } \\
\hline & & \multicolumn{8}{|c|}{$\begin{array}{l}\text { Adjusted mean annualized change (SE) per quartile category of } \\
\text { averaged intake }(\mathrm{g} / \mathrm{d})\end{array}$} & \multirow[b]{3}{*}{$P$ trend } & \multicolumn{2}{|c|}{$\beta$ (SE) per $10 \mathrm{~g} / \mathrm{d}$} & \multirow{3}{*}{$\begin{array}{c}P \\
\text { continuous }\end{array}$} \\
\hline & & \multicolumn{2}{|c|}{$19 \cdot 1$} & \multicolumn{2}{|c|}{$22 \cdot 7$} & \multicolumn{2}{|c|}{$25 \cdot 3$} & \multicolumn{2}{|c|}{$29 \cdot 6$} & & \multirow[b]{2}{*}{$\beta$} & \multirow[b]{2}{*}{ SE } & \\
\hline & & Mean & SE & Mean & SE & Mean & SE & Mean & SE & & & & \\
\hline & 3 & 0.026 & 0.004 & 0.025 & 0.004 & 0.019 & 0.004 & 0.012 & 0.004 & 0.01 & -0.0086 & 0.0039 & 0.03 \\
\hline & 4 & 0.023 & 0.005 & 0.024 & 0.004 & 0.019 & 0.004 & 0.014 & 0.004 & $0 \cdot 12$ & -0.0047 & 0.0042 & 0.26 \\
\hline \multirow[t]{4}{*}{$\mathrm{HDL}-\mathrm{C}(\mathrm{mmol} / \mathrm{l})$} & 1 & 0.014 & 0.001 & 0.013 & 0.001 & 0.013 & 0.001 & 0.017 & 0.001 & 0.06 & 0.0023 & 0.0009 & 0.01 \\
\hline & 2 & 0.013 & 0.001 & 0.013 & 0.001 & 0.013 & 0.001 & 0.017 & 0.001 & 0.004 & 0.0031 & 0.0008 & $<0.001$ \\
\hline & 3 & 0.014 & 0.001 & 0.013 & 0.001 & 0.013 & 0.001 & 0.016 & 0.001 & $0 \cdot 10$ & 0.0024 & 0.0009 & 0.01 \\
\hline & 4 & 0.014 & 0.001 & 0.013 & 0.001 & 0.013 & 0.001 & 0.016 & 0.001 & $0 \cdot 10$ & 0.0027 & 0.0010 & 0.01 \\
\hline \multirow[t]{4}{*}{ LDL-C (mmol/l) } & 1 & -0.043 & 0.003 & -0.041 & 0.003 & -0.043 & 0.003 & -0.045 & 0.002 & 0.62 & -0.0041 & 0.0024 & 0.09 \\
\hline & 2 & -0.041 & 0.003 & -0.039 & 0.003 & -0.039 & 0.002 & -0.040 & 0.002 & 0.89 & -0.0025 & 0.0023 & 0.28 \\
\hline & 3 & -0.042 & 0.003 & -0.039 & 0.003 & -0.039 & 0.003 & -0.040 & 0.002 & 0.78 & -0.0026 & 0.0025 & 0.30 \\
\hline & 4 & -0.042 & 0.003 & -0.039 & 0.003 & -0.039 & 0.003 & -0.040 & 0.003 & $0 \cdot 84$ & -0.0034 & 0.0027 & 0.21 \\
\hline \multirow[t]{4}{*}{$\mathrm{SBP}(\mathrm{mmHg})$} & 1 & 0.158 & 0.060 & 0.236 & 0.058 & 0.131 & 0.057 & 0.109 & 0.053 & 0.30 & -0.0439 & 0.0517 & 0.40 \\
\hline & 2 & 0.147 & 0.060 & 0.249 & 0.057 & 0.171 & 0.056 & 0.171 & 0.054 & 0.94 & 0.0140 & 0.0522 & 0.79 \\
\hline & 3 & 0.158 & 0.064 & 0.250 & 0.058 & 0.166 & 0.057 & 0.162 & 0.056 & 0.76 & 0.0046 & 0.0574 & 0.94 \\
\hline & 4 & 0.221 & 0.066 & 0.272 & 0.058 & 0.160 & 0.057 & 0.102 & 0.058 & 0.11 & -0.0854 & 0.0622 & $0 \cdot 17$ \\
\hline \multirow[t]{4}{*}{$\mathrm{TC}(\mathrm{mmol} / \mathrm{l})$} & 1 & -0.034 & 0.003 & -0.037 & 0.003 & -0.037 & 0.003 & -0.037 & 0.003 & 0.61 & -0.0050 & 0.0029 & 0.09 \\
\hline & 2 & -0.035 & 0.003 & -0.034 & 0.003 & -0.033 & 0.003 & -0.030 & 0.003 & 0.25 & -0.0001 & 0.0027 & 0.96 \\
\hline & 3 & -0.035 & 0.003 & -0.034 & 0.003 & -0.033 & 0.003 & -0.030 & 0.003 & 0.21 & -0.0002 & 0.0030 & 0.95 \\
\hline & 4 & -0.036 & 0.004 & -0.034 & 0.003 & -0.033 & 0.003 & -0.029 & 0.003 & 0.18 & -0.0001 & 0.0032 & 0.97 \\
\hline \multirow[t]{4}{*}{ TAG (mmol/l) } & 1 & -0.020 & 0.003 & -0.020 & 0.003 & -0.019 & 0.002 & -0.027 & 0.002 & 0.02 & -0.0060 & 0.0021 & 0.004 \\
\hline & 2 & -0.020 & 0.003 & -0.020 & 0.002 & -0.019 & 0.002 & -0.026 & 0.002 & 0.04 & -0.0049 & 0.0021 & 0.02 \\
\hline & 3 & -0.023 & 0.003 & -0.021 & 0.002 & -0.018 & 0.002 & -0.024 & 0.002 & 0.52 & -0.0025 & 0.0023 & 0.26 \\
\hline & 4 & -0.022 & 0.003 & -0.021 & 0.003 & -0.018 & 0.002 & -0.025 & 0.002 & 0.34 & -0.0037 & 0.0025 & 0.13 \\
\hline \multirow{4}{*}{ WC $(\mathrm{cm})$} & 1 & 0.591 & 0.027 & 0.608 & 0.026 & 0.499 & 0.026 & 0.426 & 0.023 & $<0.001$ & -0.1510 & 0.0229 & $<0.001$ \\
\hline & 2 & 0.577 & 0.016 & 0.549 & 0.016 & 0.516 & 0.016 & 0.472 & 0.014 & $<0.001$ & -0.0748 & 0.0134 & $<0.001$ \\
\hline & 3 & 0.575 & 0.018 & 0.551 & 0.016 & 0.518 & 0.016 & 0.474 & 0.015 & $<0.001$ & -0.0723 & 0.0149 & $<0.001$ \\
\hline & 4 & 0.570 & 0.018 & 0.549 & 0.016 & 0.518 & 0.016 & 0.479 & 0.015 & $<0.001$ & -0.0679 & 0.0162 & $<0.001$ \\
\hline \multirow[t]{4}{*}{ Weight (kg) } & 1 & 0.084 & 0.024 & 0.103 & 0.023 & 0.066 & 0.023 & 0.050 & 0.021 & 0.16 & -0.0553 & 0.0207 & 0.01 \\
\hline & 2 & 0.076 & 0.024 & 0.103 & 0.023 & 0.071 & 0.023 & 0.060 & 0.022 & 0.41 & -0.0464 & 0.0213 & 0.03 \\
\hline & 3 & 0.090 & 0.026 & 0.108 & 0.023 & 0.063 & 0.023 & 0.051 & 0.023 & 0.15 & -0.0662 & 0.0234 & 0.005 \\
\hline & 4 & 0.082 & 0.027 & 0.105 & 0.023 & 0.064 & 0.023 & 0.059 & 0.024 & 0.36 & -0.0600 & 0.0254 & 0.02 \\
\hline
\end{tabular}

DBP, diastolic blood pressure; eGFR, estimated glomerular filtration rate; FG, fasting plasma glucose; HDL-C, HDL-cholesterol; LDL-C, LDL-cholesterol; SBP, systolic blood pressure; TC, total cholesterol; WC, waist circumference.

*Model 1 was adjusted for age, sex, energy intake and the baseline measure of the outcome (i.e. the value at the beginning of the exam interval). Model 2 was adjusted as for model 1, plus smoking status, alcohol intake, pharmacological treatment for dyslipidaemia, CVD, hypertension or diabetes, and history of cancer. Model 2 also included change in weight, except for when the outcome was change in weight. Model 3 was additionally adjusted for the Dietary Guidelines for Americans 2010 Index score. Model 4 further adjusted for plant or animal protein in the animal and plant protein models, respectively.

unrestricted $^{(3,45)}$ diets with varying levels of dietary protein show few, if any, changes in glycaemic or insulin parameters, and any changes may depend more on the modification of other macronutrient intake rather than protein specifically.

We observed a modest beneficial association between protein intake and changes in eGFR. Although the importance of limiting protein intake in the context of chronic kidney disease (CKD) is well established, existing evidence on the relationship between protein intake and kidney function in generally healthy people is equivo$\mathrm{cal}^{(46)}$ but possibly beneficial ${ }^{(47)}$. Recent reviews concluded that there was no evidence to support the idea that daily protein intake up to $1.6 \mathrm{~g} / \mathrm{kg} \mathrm{BW}$ (still within the 10$35 \%$ of energy range recommended) in individuals without CKD is detrimental to health ${ }^{(48,49)}$. Trials of high protein intake in individuals without CKD have shown that it increases eGFR and other markers of renal function ${ }^{(46)}$, although it should be noted that protein intake in trials (often $>20 \%$ of energy) typically exceeds habitual consumption levels (e.g. 12-19\% of energy). A recent secondary analysis of the OmniHeart trial in otherwise healthy individuals with prehypertension or stage 1 hypertension indicated that high protein intake in the context of a healthy diet for 6 weeks increased (cystatin C-based) $\mathrm{eGFR}^{(50)}$, alongside decreasing SBP, LDL-C, HDL-C and TAG ${ }^{(51)}$. However, longer-term studies do not generate as clear cut a picture with respect to protein intake and eGFR or CKD risk. In a prospective study of Dutch adults followed up over 15 years, neither total protein intake nor any protein food source was associated with changes in (cystatin C-based) $\mathrm{eGFR}^{(47)}$. However, in those with mildly impaired eGFR, higher intakes of milk, milk products and low-fat dairy were associated with less 
decline in eGFR over time. In a very recent paper from the Atherosclerosis Risk in Communities investigators, neither total nor animal protein intake was associated with risk of incident CKD among initially healthy participants, whereas plant protein intake was associated with $24 \%$ lower risk of incident $\mathrm{CKD}^{(52)}$. In an older study using data from two nested case-control studies of postmenopausal women within the Women's Health Initiative Observational Study, biomarker-calibrated protein intake was not associated with odds of impaired renal function ${ }^{(53)}$. In addition, in 6.4 years of follow-up in the Cardiovascular Health Study of older adults, total, animal or plant protein intake was not associated with $\mathrm{eGFR}^{(54)}$. Many of these studies used cystatin-C-based estimates of eGFR, whereas we used an sCr-based equation given available data. Our use of the sCr-based measure, although taken fasting, may reflect a more acute response to protein intake (e.g. dinner the night prior to blood draw) and prevalent muscle mass, as compared with a cystatin-C-based measure, which may more effectively estimate risk associated with reduced kidney function than a creatinine-based measure ${ }^{(55)}$.

In the present study, we did not observe a relationship between protein intake and annualized changes in weight or WC, although protein from plant sources was favourably associated with changes in WC, even after controlling for weight change and protein from animal sources. Our results on total protein intake contrast with experimental evidence, such as that of the DiOGenes study and other randomized trials. A meta-analysis of short-term randomized trials (mean duration 12 weeks) suggests that higher-protein diets (20-35\% of energy) in an energyrestricted context have beneficial effects on weight loss and body composition, notably in the preservation of fatfree mass during weight loss ${ }^{(2)}$. This finding on protein's role in maintaining lean mass was supported by another meta-analysis focusing on twenty-four trials conducted specifically in older adults (>50 years) ${ }^{(7)}$. In DiOGenes, at both the 6- and 12-month maintenance follow-ups, weight regain was lower in the high-protein ( $25 \%$ of energy) than in the low-protein (13\% of energy) groups, and highprotein groups were more likely to achieve additional weight loss in the follow-up period ${ }^{(56,57)}$. In a recent reanalysis of DiOGenes investigating plant and animal protein sources, while substituting overall plant for animal protein was not associated with effects on body weight, higher plant protein specifically in the form of non-cereal sources $v$. cereal-based sources was favourably associated with body weight changes ${ }^{(41)}$.

As noted above, the dietary source of protein may play a role in cardiometabolic health, and we observed differential results based on the source of protein, be it animal or plant. Prior prospective observational literature implicates animal protein, notably red meat, but not poultry or fish, with higher risk of $\mathrm{CHD}^{(58)}$ and total mortality ${ }^{(59)}$. A recent 11-year follow-up study in Australian adults showed higher risk of metabolic syndrome with higher total and animal protein, including red meat and poultry, and lower risk with higher plant protein, notably from grains, legumes and nuts ${ }^{(22)}$. Plant, but not animal protein, was associated with favourable changes in blood pressure in a 5 -year follow-up in elderly men ${ }^{(25)}$, while in a prior Framingham Offspring study, both animal and plant protein were associated with lower risk of high blood pressure ${ }^{(26)}$. Animal protein was also associated with increases in WC, SBP and body weight across 11 years, while plant protein was associated with decreases in WC and weight ${ }^{(22)}$. Similarly, animal protein, but not plant protein, was associated with higher risk of type 2 diabetes in a meta-analysis of eleven prospective cohort studies ${ }^{(21)}$ and other prospective literature ${ }^{(20)}$. In the DiOGenes trial follow-up, meat protein intake substituted for non-meat animal protein was favourably associated with FI and insulin resistance ${ }^{(41)}$. In another recent systematic review of studies comparing plant with animal protein intake in relation to metabolic syndrome-related conditions, the authors concluded that soya protein (with isoflavones), but not soya protein alone or other plant proteins, led to greater decreases in TC and LDL-C compared with animal-sourced protein intake ${ }^{(60)}$. Future research should investigate the long-term effects on changes in cardiometabolic health of specific food sources of protein, other components (e.g. food matrices) of plant $v$. animal protein sources and/or differences in diet quality between those consuming more protein from plants or animals, and vice versa. For example, one question might be whether low-saturated-fat or high-fibre protein food sources have a different relationship with cardiometabolic health than high-saturatedfat or low-fibre protein sources.

Turning to a methodological point, we noted considerable differences in secondary analyses when protein was expressed in $\mathrm{g} / \mathrm{kg} \mathrm{BW}$ per $\mathrm{d}$, a unit of intake which ties protein to body weight and is the measure used in the Dietary Reference Intakes (e.g. RDA of $0.80 \mathrm{~g} / \mathrm{kg} \mathrm{BW}$ per $\mathrm{d}$ for most adults) ${ }^{(37)}$. Average intakes reported in the present study are in line with those of the representative US population. In a study using data from the National Health and Nutrition Examination Study (2001-2010), intake was reported in deciles ranging from a median of 0.69 in the lowest to $1.51 \mathrm{~g} / \mathrm{kg} \mathrm{BW}$ per $\mathrm{d}$ in the highest decile ${ }^{(1)}$. While we analysed intake in the present study in quartile categories of protein, if we were to express it in deciles, median values would be 0.64 in the lowest and $1.56 \mathrm{~g} / \mathrm{kg}$ $\mathrm{BW}$ per $\mathrm{d}$ in the highest decile. We observed significant and favourable associations for changes in eGFR, FG, HDL-C, TC, TAG, WC and weight when protein was expressed in $\mathrm{g} / \mathrm{kg} \mathrm{BW}$ per $\mathrm{d}$. However, it is important to recognize the degree to which excess body weight may be confounding these results. In the present sample, it is clear that while 'absolute' intake (expressed in $\mathrm{g} / \mathrm{d}$ ) was higher with higher BMI, as would be expected, there was an opposite trend when expressed in $\mathrm{g} / \mathrm{kg} \mathrm{BW}$ per $\mathrm{d}$, which suggests several important implications; one of which is 
that it may be unlikely for heavier individuals to eat enough protein to meet their theoretical requirements when such requirements are based on their actual body weight, rather than on lean or fat-free mass, or ideal body weight. This phenomenon has been observed in other studies, such as those based on national surveillance data $^{(1)}$. It is unclear how or if the protein requirements should change for overweight/obese individuals, an issue that becomes more critical when those who fall into a normal BMI range represent merely a third of the population, be it the present sample or the US population more broadly ${ }^{(61)}$. Over $45 \%$ of obese participants in the present study were not meeting the RDA expressed in terms of actual body weight, compared with only 6 and $21 \%$ of normal and overweight participants, respectively. This discrepancy was not due to obese participants reporting less absolute intake or as a percentage of energy, but rather because the RDA is expressed in terms of body weight. Discrepancies between studies about the health effects of protein intake, be they observational or experimental, may be due to the differential expression of units of intake, as well as the weight status of the study population. It should be noted that our findings could be complicated by the fact that the FFQ was designed primarily to rank individuals and approximate rather than perfectly measure absolute intake ${ }^{(36)}$, and further that obese individuals may under-report their intake ${ }^{(62)}$. Future research, including any re-evaluation of dietary requirements for protein, should be more specific regarding intake levels for the overweight and obese, or should examine requirements for lean body mass rather than total body mass, especially given the prevalence of overweight/ obesity in the USA and globally.

It is also important to note that many observational studies use theoretical substitution approaches, in which protein intake is expressed as a percentage of total energy intake, which require markedly different interpretations of protein's effects. That is, the coefficients for protein intake as a percentage of total energy must be interpreted as if protein is being substituted for either fat or carbohydrate intake. We sought an agnostic approach in this regard and adjusted for overall dietary quality instead.

\section{Strengths and limitations}

We benefited from a large cohort followed for up to 20 years with repeated measures of exposures and outcomes from which annualized changes in parameters could be derived. Although FFQ are widely used in epidemiological studies, they are not without their limitations, most notably with respect to recall and self-report biases. As mentioned, although FFQ provide good estimates of relative intake, giving us the ability to distinguish between high and low consumers of a given nutrient, they only approximate absolute intake. That said, levels of intake reported by the present study participants were consistent with those from
US surveillance data ${ }^{(1)}$. We elected to include individuals with cardiometabolic risk values that exceed cut-off points for disease definitions for several reasons: we were interested in examining changes across the typical life course, which more than often than not includes onset of treatment for cardiometabolic conditions. If we were to limit analyses to only healthy individuals, we would be examining only profoundly healthy survivors and likely drawing conclusions not applicable to the majority of individuals. Instead of excluding participants, we adjusted for treatment for hypertension, dyslipidaemia, CVD, and diabetes, as well history of cancer. We did not adjust our nominal $\alpha$ level of significance for the number of primary outcomes (ten) because a Bonferroni correction would likely be too strict. Were a correction or multiple testing implemented, a more conservative conclusion would result; namely, that our primary findings were statistically significant for SBP and FG, but not eGFR. A limitation to grouping broadly by protein source food (i.e. animal or plant) is that it does not distinguish based on other food components, such as saturated fat and fibre; however, we adjusted for overall diet quality in these analyses which should account for many of these dietary differences. In addition, residual confounding by other lifestyle factors may be influencing our results, for example, in those who rely mainly on plant protein sources. Finally, the Framingham Offspring cohort is a relatively homogeneous cohort of Caucasian Americans, which may limit the generalizability of our findings to similar populations.

\section{Conclusion}

In conclusion, in this population-based long-term prospective cohort study in middle-aged Americans, we observed that protein intake was associated with yearover-year changes in SBP, kidney function (as sCr-based eGFR) and FG. Our findings are supported by existing literature regarding protein and incident disease in initially healthy people. Methodologically, our paper raises several important points that merit further investigation, notably that results of analyses using protein expressed in $\mathrm{g} / \mathrm{kg} \mathrm{BW}$ per $\mathrm{d}$ were quite different from those expressed in $\mathrm{g} / \mathrm{d}$, indicating the need for greater analytical consistency across studies and a better understanding of the degree to which body mass and mass quality affect results, if these are to be used in making recommendations regarding intake, especially in populations in which a majority of individuals are overweight or obese.

\section{Acknowledgements}

Acknowledgements: The authors wish to thank the participants of the Framingham Heart Study for their tireless 
volunteerism and, by extension, their immense contributions to public health. Financial support: This research was supported by the US Department of Agriculture Agricultural Research Service (agreement number \#581950-4-003), and in part by the North American Branch of the International Life Sciences Institute (ILSI NA). ILSI NA is a public, non-profit foundation that provides a forum to advance understanding of scientific issues related to the nutritional quality and safety of the food supply by sponsoring research programmes, educational seminars and workshops, and publications. ILSI NA receives support primarily from its industry membership. The Framingham Heart Study of the National Heart, Lung, and Blood Institute of the National Institutes of Health and Boston University School of Medicine is supported by contract number HHSN268201500001I from the National Heart, Lung, and Blood Institute's Framingham Heart Study with additional support from other sources. The views expressed in this article are of those of the authors and do not necessarily represent the views of the funding organization. The sponsors had no role in the conduct of the study; collection, management, analysis and interpretation of the data; preparation, review or approval of the manuscript; or decision to submit the manuscript for publication. Conflict of interest: None. Authorship: P.F.J. designed the research. A.H. analysed the data and wrote the manuscript. Both authors contributed to interpreting the data, and edited, reviewed, approved and are responsible for the final content of the manuscript. Ethics of buman subject participation: This study was conducted according to the guidelines laid down in the Declaration of Helsinki. The original data collection protocols were approved by the Institutional Review Board at Boston University Medical Center and the present study protocol was reviewed by the Tufts University Health Sciences Institutional Review Board. Written informed consent was obtained from all participants.

\section{Supplementary material}

To view supplementary material for this article, please visit https://doi.org/10.1017/S1368980018001854

\section{References}

1. Pasiakos SM, Lieberman HR \& Fulgoni VL (2015) Higherprotein diets are associated with higher HDL cholesterol and lower BMI and waist circumference in US adults. J Nutr 145, 605-614.

2. Wycherley TP, Moran LJ, Clifton PM et al. (2012) Effects of energy-restricted high-protein, low-fat compared with standard-protein, low-fat diets: a meta-analysis of randomized controlled trials. Am J Clin Nutr 96, 1281-1298.

3. Campbell WW, Kim JE, Amankwaah AF et al. (2015) Higher total protein intake and change in total protein intake affect body composition but not metabolic syndrome indexes in middle-aged overweight and obese adults who perform resistance and aerobic exercise for 36 weeks. J Nutr $\mathbf{1 4 5}$, 2076-2083.

4. Longland TM, Oikawa SY, Mitchell CJ et al. (2016) Higher compared with lower dietary protein during an energy deficit combined with intense exercise promotes greater lean mass gain and fat mass loss: a randomized trial. $A m J$ Clin Nutr 103, 738-746.

5. Schwingshackl L \& Hoffmann G (2013) Long-term effects of low-fat diets either low or high in protein on cardiovascular and metabolic risk factors: a systematic review and metaanalysis. Nutr J 12, 48.

6. Hill AM, Harris Jackson KA, Roussell MA et al. (2015) Type and amount of dietary protein in the treatment of metabolic syndrome: a randomized controlled trial. Am J Clin Nutr 102, $757-770$.

7. Kim JE, O'Connor LE, Sands LP et al. (2016) Effects of dietary protein intake on body composition changes after weight loss in older adults: a systematic review and metaanalysis. Nutr Rev 74, 210-224.

8. Smith GI, Yoshino J, Kelly SC et al. (2016) High-protein intake during weight loss therapy eliminates the weightloss-induced improvement in insulin action in obese postmenopausal women. Cell Rep 17, 849-861.

9. Campos-Nonato I, Hernandez L \& Barquera S (2017) Effect of a high-protein diet versus standard-protein diet on weight loss and biomarkers of metabolic syndrome: a randomized clinical trial. Obes Facts 10, 238-251.

10. Beasley JM, Deierlein AL, Morland KB et al. (2016) Is meeting the recommended dietary allowance (RDA) for protein related to body composition among older adults? results from the Cardiovascular Health of Seniors and Built Environment Study. J Nutr Health Aging 20, 790-796

11. Berryman CE, Agarwal S, Lieberman HR et al. (2016) Diets higher in animal and plant protein are associated with lower adiposity and do not impair kidney function in US adults. Am J Clin Nutr 104, 743-749.

12. Silva TR \& Spritzer PM (2017) Skeletal muscle mass is associated with higher dietary protein intake and lower body fat in postmenopausal women: a cross-sectional study. Menopause 24, 502-509.

13. Cheng M, Wang $\mathrm{H}$, Wang $\mathrm{Z}$ et al. (2017) Relationship between dietary factors and the number of altered metabolic syndrome components in Chinese adults: a crosssectional study using data from the China Health and Nutrition Survey. BMJ Open 7, e014911.

14. Levine ME, Suarez JA, Brandhorst S et al. (2014) Low protein intake is associated with a major reduction in IGF-1, cancer, and overall mortality in the 65 and younger but not older population. Cell Metab 19, 407-417.

15. Porter Starr KN, Pieper CF, Orenduff MC et al. (2016) Improved function with enhanced protein intake per meal: a pilot study of weight reduction in frail, obese older adults. J Gerontol A Biol Sci Med Sci 71, 1369-1375.

16. McLean RR, Mangano KM, Hannan MT et al. (2016) Dietary protein intake is protective against loss of grip strength among older adults in the Framingham Offspring Cohort. J Gerontol A Biol Sci Med Sci 71, 356-361.

17. Mangano KM, Sahni S, Kiel DP et al. (2017) Dietary protein is associated with musculoskeletal health independently of dietary pattern: the Framingham Third Generation Study. Am J Clin Nutr 105, 714-722.

18. Lagiou P, Sandin S, Lof M et al. (2012) Low carbohydratehigh protein diet and incidence of cardiovascular diseases in Swedish women: prospective cohort study. BMJ 344, e4026.

19. Hernández-Alonso P, Salas-Salvadó J, Ruiz-Canela M et al. (2016) High dietary protein intake is associated with an increased body weight and total death risk. Clin Nutr $\mathbf{3 5}$, 496-506. 
20. Malik VS, Li Y, Tobias DK et al. (2016) Dietary protein intake and risk of type 2 diabetes in US men and women. Am J Epidemiol 183, 715-728.

21. Shang X, Scott D, Hodge AM et al. (2016) Dietary protein intake and risk of type 2 diabetes: results from the Melbourne Collaborative Cohort Study and a meta-analysis of prospective studies. Am J Clin Nutr 104, 1352-1365.

22. Shang X, Scott D, Hodge A et al. (2017) Dietary protein from different food sources, incident metabolic syndrome and changes in its components: an 11-year longitudinal study in healthy community-dwelling adults. Clin Nutr 36, $1540-1548$.

23. Fung TT, van Dam RM, Hankinson SE et al. (2010) Lowcarbohydrate diets and all-cause and cause-specific mortality: two cohort studies. Ann Intern Med 153, 289-298.

24. Trichopoulou A, Psaltopoulou T, Orfanos P et al. (2007) Low-carbohydrate-high-protein diet and long-term survival in a general population cohort. Eur J Clin Nutr 61, 575-581.

25. Tielemans SM, Kromhout D, Altorf-van der Kuil W et al. (2014) Associations of plant and animal protein intake with 5-year changes in blood pressure: the Zutphen Elderly Study. Nutr Metab Cardiovasc Dis 24, 1228-1233.

26. Buendia JR, Bradlee ML, Singer MR et al. (2015) Diets higher in protein predict lower high blood pressure risk in Framingham Offspring Study adults. Am J Hypertens 28, 372-379.

27. Zaslavsky O, Zelber-Sagi S, Hebert JR et al. (2017) Biomarker-calibrated nutrient intake and healthy diet index associations with mortality risks among older and frail women from the Women's Health Initiative. Am J Clin Nutr 105, 1399-1407.

28. Feinleib M, Kannel WB, Garrison RJ et al. (1975) The Framingham Offspring Study. Design and preliminary data. Prev Med 4, 518-525.

29. Martin SS, Blaha MJ, Elshazly MB et al. (2013) Comparison of a novel method vs the Friedewald equation for estimating low-density lipoprotein cholesterol levels from the standard lipid profile. JAMA 310, 2061-2068.

30. Fox CS (2004) Predictors of new-onset kidney disease in a community-based population. JAMA 291, 844-850.

31. Coresh J, Astor BC, McQuillan G et al. (2002) Calibration and random variation of the serum creatinine assay as critical elements of using equations to estimate glomerular filtration rate. Am J Kidney Dis 39, 920-929.

32. Levey AS, Stevens LA, Schmid CH et al. (2009) A new equation to estimate glomerular filtration rate. Ann Intern Med 150, 604-612.

33. McMahon GM, Hwang S-J \& Fox CS (2016) Residual lifetime risk of chronic kidney disease. Nephrol Dial Transplant 32, $1705-1710$

34. Matthews DR, Hosker JP, Rudenski AS et al. (1985) Homeostasis model assessment: insulin resistance and $\beta$-cell function from fasting plasma glucose and insulin concentrations in man. Diabetologia 28, 412-419.

35. Rimm EB, Giovannucci EL, Stampfer MJ et al. (1992) Reproducibility and validity of an expanded selfadministered semiquantitative food frequency questionnaire among male health professionals. Am J Epidemiol 135, 1114-1126.

36. Willett W (1998) Nutritional Epidemiology. New York: Oxford University Press.

37. Institute of Medicine (2005) Dietary Reference Intakes for Energy, Carbohydrate, Fiber, Fat, Fatty Acids, Cholesterol, Protein, and Amino Acids (Macronutrients). Washington, DC: The National Academies Press.

38. Sauder KA, Proctor DN, Chow M et al. (2015) Endothelial function, arterial stiffness and adherence to the 2010 Dietary Guidelines for Americans: a cross-sectional analysis. $\mathrm{Br} J$ Nutr 113, 1773-1781.

39. Rebholz CM, Friedman EE, Powers LJ et al. (2012) Dietary protein intake and blood pressure: a meta-analysis of randomized controlled trials. Am J Epidemiol 176, Suppl. 7, S27-S43.

40. Tielemans SM, Altorf-van der Kuil W, Engberink MF et al. (2013) Intake of total protein, plant protein and animal protein in relation to blood pressure: a meta-analysis of observational and intervention studies. J Hum Hypertens 27, 564-571.

41. van Baak M, Larsen T, Jebb S et al. (2017) Dietary intake of protein from different sources and weight regain, changes in body composition and cardiometabolic risk factors after weight loss: the DIOGenes study. Nutrients $\mathbf{9}$, E1326.

42. Santesso N, Akl EA, Bianchi M et al. (2012) Effects of higher- versus lower-protein diets on health outcomes: a systematic review and meta-analysis. Eur J Clin Nutr 66, 780-788.

43. Bray GA, Redman LM, de Jonge L et al. (2016) Effect of three levels of dietary protein on metabolic phenotype of healthy individuals with 8 weeks of overfeeding. J Clin Endocrinol Metab 101, 2836-2843.

44. Johnstone AM, Lobley GE, Horgan GW et al. (2011) Effects of a high-protein, low-carbohydrate $v$. high-protein, moderate-carbohydrate weight-loss diet on antioxidant status, endothelial markers and plasma indices of the cardiometabolic profile. Br J Nutr 106, 282-291.

45. Morenga LT, Williams S, Brown R et al. (2010) Effect of a relatively high-protein, high-fiber diet on body composition and metabolic risk factors in overweight women. Eur J Clin Nutr 64, 1323-1331.

46. Schwingshackl L \& Hoffmann G (2014) Comparison of high vs. normal/low protein diets on renal function in subjects without chronic kidney disease: a systematic review and meta-analysis. PLoS One 9, e97656.

47. Herber-Gast G-CM, Biesbroek S, Verschuren WM et al. (2016) Association of dietary protein and dairy intakes and change in renal function: results from the population-based longitudinal Doetinchem cohort study. Am J Clin Nutr 104, 1712-1719.

48. Leidy HJ, Clifton PM, Astrup A et al. (2015) The role of protein in weight loss and maintenance. Am J Clin Nutr 101, issue 6, 1320S-1329S.

49. Cuenca-Sánchez M, Navas-Carrillo D \& Orenes-Piñero E (2015) Controversies surrounding high-protein diet intake: satiating effect and kidney and bone health. Adv Nutr 6, 260-266.

50. Juraschek SP, Appel LJ, Anderson CAM et al. (2013) Effect of a high-protein diet on kidney function in healthy adults: results from the OmniHeart trial. Am J Kidney Dis 61, 547-554.

51. Appel LJ, Sacks FM, Carey VJ et al. (2005) Effects of protein, monounsaturated fat, and carbohydrate intake on blood pressure and serum lipids: results of the OmniHeart randomized trial. JAMA 294, 2455-2464.

52. Haring B, Selvin E, Liang M et al. (2017) Dietary protein sources and risk for incident chronic kidney disease: results from the Atherosclerosis Risk in Communities (ARIC) study. J Ren Nutr 27, 233-242.

53. Beasley JM, Aragaki AK, LaCroix AZ et al. (2011) Higher biomarker-calibrated protein intake is not associated with impaired renal function in postmenopausal women. J Nutr 141, 1502-1507.

54. Beasley JM, Katz R, Shlipak M et al. (2014) Dietary protein intake and change in estimated GFR in the Cardiovascular Health Study. Nutrition 30, 794-799.

55. Shlipak MG, Matsushita K, Ärnlöv J et al. (2013) Cystatin C versus creatinine in determining risk based on kidney function. $N$ Engl J Med 369, 932-943.

56. Larsen TM, Dalskov S-M, van Baak M et al. (2010) Diets with high or low protein content and glycemic index for weightloss maintenance. $N$ Engl J Med 363, 2102-2113. 
57. EEJG Aller, Larsen TM, Claus H et al. (2014) Weight loss maintenance in overweight subjects on ad libitum diets with high or low protein content and glycemic index: the DIOGENES trial 12-month results. Int J Obes (Lond) 38, 1511-1517.

58. Bernstein AM, Sun Q, Hu FB et al. (2010) Major dietary protein sources and risk of coronary heart disease in women. Circulation 122, 876-883.

59. Pan A, Sun Q, Bernstein AM et al. (2012) Red meat consumption and mortality: results from two prospective cohort studies. Arch Intern Med 172, 555-563.
60. Chalvon-Demersay T, Azzout-Marniche D, Arfsten J et al. (2017) A systematic review of the effects of plant compared with animal protein sources on features of metabolic syndrome. J Nutr 147, 281-292.

61. Ogden CL, Carroll MD, Kit BK et al. (2014) Prevalence of childhood and adult obesity in the United States, 2011-2012. JAMA 311, 806-814.

62. Wehling H \& Lusher J (2017) People with a body mass index $\geq 30$ under-report their dietary intake: a systematic review. J Health Psychol. Published online: 1 Jul 2017. doi: $10.1177 / 1359105317714318$ 